\title{
TYPICAL MISTAKES IN THE WRITING SPEECH OF BILINGUAL STUDENTS
}

\author{
Irina Aleksandrovna Dinevich* \\ https://orcid.org/0000-0003-1071-3437
}

\begin{abstract}
RECIBIDO: Mayo 2021 / ACEPTADO: Julio 2021 / PUBLICADO: Septiembre 2021
\end{abstract}
Como citar: Dinevich, Irina Aleksandrovna. (2021) Typical mistakes in the writing speech of bilingual students. Telos: revista de Estudios Interdisciplinarios en Ciencias Sociales, 23 (3), Venezuela. (Pp. 602-615).

DOI: www.doi.org/10.36390/telos233.07

\begin{abstract}
This article is devoted to considering of the phenomenon of bilingualism from the point of view of linguistic, psycholinguistic, psychological, and pedagogical aspects, the characteristics of typical mistakes that bilingual students make in writing when studying the lexical and grammatical norms of the modern Russian literary language. The article discusses scientific approaches to describing the problem of bilingualism by Russian and foreign authors (Avrorin, 1972; Shcherba, 1974; Vereshchagin, 2014; Weinreich, 1972; Agar, 1994; Breton, 1991; Lambert, 1963). The methodological basis of the research is made up of general scientific methods: the method of complex theoretical analysis of the problem under study, logical methods of analysis of scientific concepts, methodological analysis of 16 written works of bilingual students 1st year in the discipline "Business communications and speech culture". The result of the research is a description of typical lexical and grammatical errors in the written language of bilingual students, and the presentation of practical recommendations for increasing the effectiveness of students' mastering of the norms of the Russian literary language. It is concluded that deep involvement in the language content plan, modern knowledge of the lexical and grammatical norms of the modern Russian literary language will help bilingual students competently express their thoughts in oral and written speech form and be active participants in effective intercultural communication.
\end{abstract}

Keywords: Bilingualism; bilinguals; Russian language; psycholinguistics; communicative competence; language interference; lexical norms; grammatical norms.

\footnotetext{
* Candidate of Philological Sciences, Associate Professor, Associate Professor, Peoples ' Friendship University of Russia, Department of Russian Language No. 2, Faculty of Russian Language and General Education Disciplines. E-mail: dinevich_irina@mail.ru
} 


\section{Errores típicos en la escritura del habla de estudiantes bilingües}

\section{RESUMEN}

Este artículo está dedicado a la consideración del fenómeno del bilingüismo desde el punto de vista de los aspectos lingüísticos, psicolingüísticos, psicológicos y pedagógicos, las características de los errores típicos que los estudiantes bilingües cometen en la escritura al estudiar las normas léxicas y gramaticales de la lengua literaria rusa moderna. El artículo discute los enfoques científicos para la descripción del problema del bilingüismo por autores rusos y extranjeros (Avrorin, 1972; Shcherba, 1974; Vereshchagin, 2014; Weinreich, 1972; Agar, 1994; Breton, 1991; Lambert, 1963). La base metodológica de la investigación se compone de métodos científicos generales: el método de análisis teórico complejo del problema en estudio, métodos lógicos de análisis de conceptos científicos, análisis metodológico de trabajos escritos de estudiantes bilingües. El resultado de la investigación es una descripción de errores léxicos y gramaticales típicos en el lenguaje escrito de estudiantes bilingües, así como la presentación de recomendaciones prácticas para aumentar la eficacia del dominio de los estudiantes de las normas de la lengua literaria rusa. Se concluye que la participación profunda en el plan de contenido del idioma, el conocimiento moderno de las normas léxicas y gramaticales del idioma literario ruso moderno ayudarán a los estudiantes bilingües a expresar sus pensamientos de manera competente en formas orales y escritas de habla y a ser participantes activos en una comunicación intercultural efectiva.

Palabras Clave: Bilingüismo; bilingües; lengua rusa; psicolingüística; competencia comunicativa; interferencia lingüística; normas léxicas; normas gramaticales.

\section{Introduction}

The dynamic development of a multicultural and multilingual society, the promotion of the Russian language throughout the multilingual world dictates the development of the interest of researchers of the world professional community in various aspects of the phenomenon of "bilingualism".

The relevance of studying the problem of bilingualism today is increasing in connection with the globalization processes taking place in modern society, the number of bilinguals in the world increasing every year, aside from the communication of people of different language groups in various spheres of society. "In the modern world, bilingualism is becoming an increasingly widespread phenomenon due to intensive and long-term contacts between peoples" (Mechkovskaya, 2000). In the context of the intercultural development of modern society, it is important to adequately understand the patterns of mastering the Russian language and the formation of an appropriate linguo-didactic basis for teaching it to bilingual students.

The number of bilingual students studying in the areas of training "Hospitality", "Tourism", "Service" is increasing at the Peoples' Friendship University of Russia every year. 1st year students face several difficulties associated with mastering the modern norms of the Russian literary language, while studying the discipline "Business communications and culture of speech." Knowledge of the psycholinguistic characteristics of bilingual students will help the teacher find an individual approach to each student, to form stable knowledge, skills, and abilities of the active use of the linguistic structures of the Russian language in oral and written forms. 
Typical mistakes in the writing speech of bilingual students.

The purpose of the article is to consider the phenomenon of bilingualism from the point of view of the linguistic, psycholinguistic, psychological, and pedagogical aspects to characterize the typical mistakes that bilingual students have when studying the lexical and grammatical norms of the modern Russian literary language.

\section{Literature review}

Bilingualism is a multidimensional phenomenon that cannot be studied within a single scientific discipline. Since "each of the aspects of bilingualism sometimes acts as an interdisciplinary problem requiring the efforts of a number of related sciences, since the linguistic aspect is inevitably intertwined in it by the psychological, and the psychological is intertwined with the pedagogical, literary and artistic intertwines with the linguistic" (Mikhailov, 1988).

Currently, there are many definitions and classifications of bilingualism that consider this linguistic phenomenon in various aspects: linguistic, sociolinguistic, psycholinguistic, psychological and pedagogical, communicative, linguistic and cultural, etc. The scientific works of many domestic and foreign researchers are devoted to theoretical systematization on issues related to the description of linguistic contacts and bilingualism (Avrorin, 1972; Shcherba, 1974; Vereshchagin, 2014; Agar, 1994; Breton, 1991; Gardy and Lafon, 1981; Grosjean, 1989; Ludi, 1990; Sussman, 1989; Friedrich 1989; Risager, 2005; Lambert, 1963).

Within the framework of the linguistic aspect of the study of bilingualism, scientists describe the intra-structural processes taking place in the conditions of the development of bilingualism, and analyze the distinctive features of bilingualism at all levels of the language: phonetic, lexical-semantic, grammatical, stylistic, etc.

Bilingualism as a social phenomenon was first studied by Russian and foreign scientists at the end of the 19th century within the framework of the theory of language interaction in a comparative-comparative aspect. Later, bilingualism began to be considered in a real communicative environment (Weinreich, 1972; Haugen, 1972). Scientific research of the late 19th - early 20th centuries was devoted to describing the process of language interaction. Whereas that the process of language contacts and the mechanism of interlanguage interaction were not considered.

One of the first linguists who studied bilingualism as "the ability of certain groups of the population to explain themselves in two languages" was academician L.V. Shcherba (Shcherba, 1974). V.A. Avrorin introduced the concept of "bilingualism" in 1938, by which he understood "equally fluency in two languages" (Avronin, 1972).

The same concept of bilingualism is found in the scientific works of many Russian representatives of the linguistic direction (Vladimirova, 2016; Mikhailov, 1988), and foreign scientists' works. For example, L. Bloomfield characterized bilingualism as "perfected the same proficiency in two languages native and non-native" (Bloomfield, 1970).

E. Haugen, the creator of the theory of linguistic contacts, on the contrary, believed that with bilingualism, the degree of proficiency in one of the languages could be quite low (Haugen, 1972). The American scientist W. Weinreich defined bilingualism as "the practice of alternating the use of two languages." "Persons carrying out this practice are called bilingual or bilingual (Weinreich, 1979).

Based on various criteria in assessing bilingualism, researchers distinguish the following types of bilingualism: 
- Subordinate bilingualism (a person speaks one language better than another) / coordinative bilingualism (a person speaks different languages equally fluently),

- Active bilingualism (a person more or less regularly refers to both languages) / passive bilingualism (a person often refers to one of the languages). Active bilingualism can, in turn, be differentiated into "pure bilingualism" and "mixed bilingualism" (Shcherba, 1974),

- Contact bilingualism (observed when maintaining a bilingual connection with native speakers) I non-contact bilingualism (lack of such communication),

- Autonomous bilingualism (languages are acquired by a person without consistently correlating them with each other) / parallel bilingualism (mastering one of the languages is based on mastering another language).

The Dictionary of Ethnolinguistic Concepts and Terms presents the following types of bilingualism: active bilingualism (natural, when a second / non-native language is acquired in the process of direct communication with native speakers of a second language), asymmetric bilingualism (asymmetric / unequal relations are established between participants in the communicative process), symmetric bilingualism (speakers two languages are equal in the social-role sense), artificial bilingualism (the acquisition of a second language occurs in the process of learning it in a didactic way) (Isaev, 2003).

Foreign linguist M. Baker distinguished between «balanced bilingualism» and "dominant bilingualism» (Baker and Jones, 1998). It is noted in the linguistic dictionary "The Concise Oxford Dictionary of Linguistics": "Bilinguals, able to equally control the use of each language, are characterized by absolute, true, ideal or balanced bilingualism" (Matthews, 1997).

The psycholinguistic aspect of the study of bilingualism provides for the consideration of bilingualism from the point of view of acts of speech production, in which the quality and level of mastering a particular language and the level of proficiency in the language, speech, and sociocultural competencies are manifested. This approach was first presented by L.V. Shcherba (Shcherba, 1974), and later found reflection in a number of scientific works of domestic and foreign linguists (Weinreich, 1972; Lambert, 1963).

Various experimental data confirm that bilingualism has a single perception system and two separate speech production systems in the native and non-native languages. This aspect has a wide problems' range in scientific research, in which the student's foreign language abilities are considered, which serve as a psychological prerequisite for the formation of bilingualism, the connection of psycholinguistic problems of bilingualism with the method of teaching a foreign language, and the mutual influence of speech development in the native and foreign languages.

As a result of many experiments, W. Lambert and his colleagues confirmed the psychic reality of the proposed division into pure and mixed types of bilingualism (Lambert, 1963). Pure bilingualism is observed in cases where one language is used in the family, and another language is the language of instruction. Therefore, during the educational process, a bilingual must apply all knowledge, skills, and abilities that correspond to the environment of the studied language. Mixed bilingualism occurs whether a bilingual in the same situation use two languages equally. Resulting in free interchangeability of the two languages.

Russian linguist E.M. Vereshchagin in the scientific work "Psychological and methodological characteristics of bilingualism (bilingualism)" (Vereshchagin, 2014) considered the receptive, reproductive and productive types of bilingualism. The scientist noted, characterizing these types: "Both receptive bilingualism and reproductive provide only the 
Typical mistakes in the writing speech of bilingual students.

perception of foreign language speech. That means that a bilingual, whose skill is characterized in the above terms, is able to understand a foreign language text, i.e. to attribute to it a certain content side" (Vereshchagin, 2014). E.M. Vereshchagin defined productive bilingualism as "the ability of a person to construct integral meaningful utterances belonging to the secondary linguistic system" (Vereshchagin, 2014).

The psychological and pedagogical aspect of the study of bilingualism is based primarily on the linguistic and psycholinguistic aspects, and provides for the development and application of "methods of teaching two languages, methods of studying the process of mastering, mastering two languages in a bilingual environment" (Vishnevskaya, 1997).

From the point of view of the psychological and pedagogical direction, scientists consider the social and linguistic aspects of bilingualism and intercultural communication (Mullagayanova, 2016), analyze the need for bilingual education as a means of professional training (Milrud and Maksimova, 2017). Moreover, they describe the specifics of teaching linguistic disciplines to bilingual students in the context of informatization of language education (Bayatyan, 2015).

The pedagogical aspect of the study of bilingualism is presented in numerous modern publications (Belkova, 2014; Bryksina, 2016; Vladimirova, 2016; Magomedova, 2016). Many authors describe the prospects for bilingual education in the higher education system (Kushnyr, 2017; Kruchinina, 2015; Maksimova and Sarimova, 2015); Ryazapova and Rozhina, 2008). The linguodidactic foundations of ethno-oriented teaching of the Russian language to representatives of certain ethnic groups in the conditions of the linguistic environment and outside it were formulated by T.M. Balykhina (Balykhina, 2007). Difficulties in the perception and understanding of a literary text by bilingual students are considered in the research of N.L. Kolchikova, L.I. Chebodaeva (Kolchikova and Chebodaeva, 2018). The didactic potential of bilingualism in teaching a foreign language is considered in the scientific work of M.V. Mosin (Mosin, 2017).

A number of works analyze the experience of organizing bilingual and multilingual education in the context of the linguistic situation in the countries of the near and far abroad (Derbisheva, 2015; Kaspers, 2017). Z.V. Polivara described the features of linguistic interference in the situation of artificial Russian-Tatar bilingualism and presented a model for the formation and correction of lexical and grammatical categories in bilingual children (Polivara, 2012). E.A. Kondrashkina examined the features of the functioning of the Russian language in the four FinnoUgric republics of the Russian Federation (Kondrashkina, 2019). G.A. Dyrheeva made a sociolinguistic survey of the living speech of students in Buryatia (Dyrheeva, 2017).

\section{Materials and methods}

The research was carried out among students of the programs "Hospitality", "Tourism", "Service" on the basis of the Peoples' Friendship University of Russia. Bilingual students are native speakers of their native languages (Uzbek, Tajik, Kyrgyz, Turkmen) and Russian. They study the discipline "Business communications and culture of speech" in the 1st year. The number of foreign students is 16 people, of which 8 are Uzbek speakers, 3 are Tajik, 3 are Turkmen, and 2 are Kyrgyz.

The methodological basis of the study was made up of the following general scientific methods: 
- The method of complex theoretical analysis of the problem under study, including the analysis of modern scientific literature on the issue of considering the phenomenon of bilingualism in various aspects,

- Logical methods of analysis of scientific concepts,

- Methodological analysis of written works performed by bilingual students in order to characterize their typical grammatical and speech errors.

Scientific research includes two stages. At first, the basic theoretical and methodological provisions for posing the problem were determined, the phenomenon of bilingualism was considered from the point of view of linguistic, psycholinguistic, psychological, and pedagogical aspects. The second stage is devoted to the methodological analysis of students' written works in the discipline "Business communications and culture of speech" to identify and characterize typical lexical and grammatical errors encountered among bilingual students.

\section{Problem statement}

The course "Business communications and culture of speech" gives students an idea of the peculiarities of oral and written forms of speech, the norms, and styles of the modern Russian literary language, the basics of business communication. The study of lexical and grammatical norms of the modern Russian literary language helps to increase the linguistic and communicative competencies necessary for bilingual students. Thus, to participate actively in intercultural communication. Bilingual competencies are formed in the process of teaching Russian as a second or foreign language and are not sufficiently developed at the initial stage of learning Russian. Since "... a bilingual person does not fully own the mechanisms of generating speech in a second language, has a small vocabulary. Therefore various kinds of interference errors (phonetic, lexical, grammatical) are allowed in his speech" (Dosanova, 2015).

Linguistic interference occurs after the contact of languages and applyning the norms of one language in another in written and oral speech. E. Haugen described interference as "cases of deviation from the norms of each language that occur in the speech of bilinguals as a result of their acquaintance with more than one language" (Haugen, 1972). W. Weinreich distinguishes between interference in speech and interference in the language (Weinreich, 1979). Speech interference is phonetic, and linguistic interference is lexical and grammatical types of interference.

The study investigated linguistic interference cases that occurs among bilingual students when studying the lexical and grammatical norms of the modern Russian literary language in the course "Business communications and speech culture".

As a result of a number of written works, it was revealed that approximately $80 \%$ of the considered group of bilinguals exhibit a coordinated type of bilingualism (proficiency in the native language and Russian is equally fluent). Students do not have a subordinate form (command of the Russian language is better than their native language). All students have a contact type of bilingualism, when communication with native speakers of the native and Russian languages is constantly maintained, as well as parallel bilingualism, in which mastery of one of the languages is based on mastering another language.

All bilingual students studied Russian at schools in their home countries, so they have developed reading, listening, and speaking skills at a sufficiently high level; however, the 
vocabulary in the scientific and official business spheres of communication is rather scarce. In addition, foreign bilingual students have insufficient regional knowledge of the Russian sociocultural environment since the formation of their personality took place under the significant influence of the cultures of the countries from which they came.

The type of bilingualism of the studied group of students has been determined; further, the cases of interference arising in mastering the lexical and grammatical norms of the modern Russian literary language are considered. Note that one of the methods of teaching linguistic material is comparative-contrastive, which allows taking into account the ethnic characteristics of bilingual students and using their linguistic experience in their native and Russian languages. Based on the written work results performed by bilingual students in the discipline "Business Communication and Speech Culture", we analyzed typical mistakes, dividing them into two groups. The first group presents speech errors associated with a violation of the lexical norms of the Russian language, and the second group presents grammatical errors that demonstrate gaps in knowledge of the morphological and syntactic norms of the Russian language.

\section{Research results}

The factual material is presented in the form of specific examples taken from written works, and the correct options are given in brackets.

\section{Speech errors associated with violation of the lexical norms of the Russian language Mixing of paronyms - words that are similar in sound and morphemic composition but differing in lexical meaning}

Errors associated with the choice of paronyms, synonyms, the lexical combination of words are one of the main problems for bilingual students since when translating words using a dictionary, students choose options in the familiar contexts of their native language. These contexts, as a rule, rarely coincide. Therefore, students with a coordinative type of bilingualism, with a certain ease, complete various tasks in the vocabulary of the Russian language while relying on their native language and finding equivalents in it. Students who do not speak Russian at a sufficiently high level have certain difficulties in determining a word's lexical meaning and therefore make mistakes in assignments when choosing appropriate paronyms. For example, in the sentence Эти фоотографии сохранились в семье потому, что моя бабушка очень (бережная, бережливая) (These photos were preserved in the family because my grandmother is very (careful, thrifty)) bilingual students chose the adjective бережная (бережливая) careful, thrifty), and in the sentence Любой (поступок, проступок) заслуживает осуждения (Аnу (deed, offense) deserves condemnation) in most cases, the students noted the lexeme nocmynoк (deed), that is also a lexical error.

\section{Mixing phraseological units - stable combinations of words characteristic of a particular language}

This error is the most frequent since each word has its own lexico-phraseological compatibility, which is inherent only in this particular word in this particular language. The meaning of phraseological units, as a rule, has a different meaning in the native bilingual language. The obvious differences in the actual linguistic information, lexical and phraseological compatibility, as well as completely different sociolinguistic connotations due to culture, customs, 
traditions of different peoples, affect the semantics and use of the word. Therefore, for a correct interpretation of the semantics of a stable turnover of Russian speech, a bilingual student needs to know not only the lexical meaning of the word but also needs to have linguocultural knowledge, i.e. understand what semantic function this word performs in Russian as a real means of communication.

Bilingual students make lexical errors in tasks involving the choice of words used in the above phraseological units. For example, in constructions: на ловца и (животное, птица, зверь) бежит; (черепашьим, гусиным, кошачьим) шагом; вставлять (сучья, бревна, палки) в колеса; заварить (суп, кашу, чай); как (мышь, птица, белка) в колесе (animal, bird, beast) runs to the catcher; (turtle, goose, cat) step; insert (branches, logs, sticks) into the wheels; brew (soup, porridge, tea); like (mouse, bird, squirrel) in a wheel) bilingual students mistakenly choose options: на ловца и животное бежит (на ловца и зверь бежит) (the ball comes to the player) and заварить чай (заварить кашу) (to stir up trouble).

Finding synonymous phraseological units also causes certain difficulties for bilinguals. For example, in some lexemes: капля в море (ломать комедию, кот наплакал, важная птица); голову морочить (терять голову, заговаривать зубы, душа в душу); считать ворон (набивать себе цену, с жиру беситься, летать в облаках); сидеть сложа руки (заварить кашу, бить баклуши, терять голову) (drop in the ocean (to put on an act, next to nothing, important bird); to take for a ride (lose your head, to fool by fine words, in perfect harmony); twiddling their thumbs (picking up a price for yourself, to behave in a fussy); to be idle (to stir up trouble, twiddling their thumbs, lose one's head) students chose the wrong options as synonymous: тертый калач - сам себе хозяин (стреляный воробей), считать ворон с жиру беситься (летать в облаках) (old bird - own master (old bird), twiddling their thumbs - to behave in a fussy (have your head in the clouds).

\section{Pleonasm is a speech excess, the use of a combination of words, in which the meaning of one word is already embedded in the meaning of another.}

This lexical error is associated with ignorance of the exact meaning of the word, especially borrowed by the Russian language, and as a result of this, the use of an unnecessary word from the point of view of the meaning. Sentences that use pleonasm are very difficult for bilingual students. Bilinguals do not find lexical errors in such constructions as: Рабочие вновь возобновили работу в сентябре месяце (Рабочие возобновили работу в сентябре). Свою автобиографию я вам уже рассказал (Автобиографию я вам уже рассказал). Они впервые познакомились на дружеской вечеринке. (Они познакомились на дружеской вечеринке).

Перевести на английский язык все русские примеры.

\section{Grammatical errors associated with the violation of the morphological and syntactic norms of the Russian language}

Many errors of this type appear due to poor assimilation of grammatical material by students, and under the interference influence of the native language. The written work results of bilingual students show grammatical errors made in the texts of different functional styles of the modern Russian literary language. 
Typical mistakes in the writing speech of bilingual students.

\section{Errors in the structure of a word during word formation}

Bilingual students make mistakes in the following lexemes in the tasks to identify grammatical violations: индидент (инцидент), (incident), подскользнуться (поскользнуться), (slip), благородность (благородство), (поbility), инженера (инженеры), (engineers), без тюли (без тюля), (without tulle), более лучшая (более хорошая), (nicer). These errors are associated either with the wrong choice of the component part of the word (root morpheme, suffix, prefix, ending), or with the wrong use of inflection in declension.

\section{Errors in the structure of the phrase during coordination and management}

Typical mistakes of bilingual students are as follows: красивый песня-романс (красивая песня-романс), (beautiful song-romance), русский и английский язык (русский и английский языки), (Russian and English), обоим девушкам (обеим девушкам), (for both girls), nо приезду из отпуска, по приходу домой (по приезде из отпуска, по приходе домой), (upon arrival from vacation, upon arrival home). Errors in the given phrases consist in the mismatch of the main and dependent words, as well as in the violation of the control form of one word from another.

\section{Errors in the structure of the sentence}

Such errors occur when the predicate is coordinated with the subject, when constructing sentences with homogeneous members, participial and adverbial phrases, and constructing complex sentences. Here are examples of frequency errors noted in the written works of bilingual students:

a) errors in violation of the connection between the subject and the predicate and the incorrect definition of the number and / or gender of the subject: Прошли сто лет (Прошло сто лет). Я с другом были в Историческом музее (Я с другом был в Историческом музее) (I was with a friend in the Historical Museum):

b) errors in the inconsistency of the forms of homogeneous members of the sentence: Поступок этот был жестоким и необъясним с точки зрения свидетелей (Поступок этот был жестоким и необъяснимым с точки зрения свидетелей) (This act was cruel and inexplicable from the point of view of witnesses);

c) errors associated with the semantic gap between the noun being defined and the participial turnover: Эти люди сделали очень много для своей страны, отдавшие жизнь во имя свободы (Эти люди, отдавшие жизнь во имя свободы, сделали очень много для своей страны). (These people, who gave their lives in the name of freedom, did a lot for their country) d) errors associated with the incorrect use of the verbal adverb: Прочитав очерк, его герои стали для меня примером (Когда я прочитал очерк, его герои стали для меня примером). (When I read the essay, his characters became an example for me.)

e) errors when building a complex sentence: Автор выражает своё отношение к проблеме, но он даёт возможность читателю согласиться или не согласиться $c$ ним (... и он даёm ...). (The author expresses his attitude to the problem and he gives the reader the opportunity to agree or disagree with him) 
The analysis of written works performed by bilingual students shows that when studying the discipline "Business communications and speech culture" it is necessary to pay special attention to the in-depth study of modern norms of the Russian literary language, to develop the necessary set of tasks that reinforce the study of such lexical topics as: "Paronyms", "Phraseologisms", "Lexical collocation of words", as well as grammatical topics: "Coordination and management", "Homogeneous members of the sentence", "Participle", "Syntax of simple and complex sentences".

When working out the norms of vocabulary and stylistics, bilingual students should not memorize individual words used in different meanings but the most stable lexical combinations inherent in the Russian language. Particular attention should be paid to the peculiarities of speech use of additional semantic loads, cultural and historical connotations of language, and speech units since a deep knowledge of these realities will contribute to the correct understanding of phenomena and facts related to everyday reality of the Russian people.

To achieve the grammatical correctness of Russian speech, it is necessary to develop the skills of bilingual students to differentiate grammatical forms and constructions according to their stylistic significance, compliance, or non-compliance with the grammatical norms of the Russian language.

Thus, these types of educational work will contribute to expanding the communicative and linguistic competencies of bilingual students and their effective intercultural communication.

\section{Conclusion}

Summing up the above, we can conclude that bilingualism as a communicative phenomenon is a widespread phenomenon and one of the key concepts of linguistics, sociolinguistics, psycholinguistics, pedagogy. In the international scientific community, the phenomenon of bilingualism is considered as a complex, systemic education in linguistic, psycholinguistic, psychological, pedagogical, and other aspects.

The existing classifications of types, types, and varieties of bilingualism reflect different criteria in its assessment. Most often, scientists consider the conditions for the formation of bilingualism, including such signs as the nature of the connection with thinking, the degree of proficiency in a second language, the way the speech mechanisms are related to each other, and the degree of their stability, the duration and stability of language contact, the degree of difference between the languages in contact (the number of discrepancies and correspondences between the structures of the native and the studied languages), the degree of kinship of languages, the nature of the communication situation, among others.

The results of written work on the course "Business communications and culture of speech" showed that bilingual students with coordinative, contact and parallel types of bilingualism make speech and grammatical errors associated with a violation of the lexical, morphological and syntactic norms of the Russian language. When teaching linguistic material, it is necessary to use a comparative-contrastive method, which makes it possible to consider the ethnic characteristics of bilingual students and use their linguistic experience in their native and Russian languages.

A deep understanding of the language content, up-to-date knowledge of the lexical and grammatical norms of the modern Russian literary language will allow bilingual students to 
Typical mistakes in the writing speech of bilingual students.

competently express their thoughts in oral and written forms of speech and be active participants in effective intercultural communication.

\section{Bibliographic References}

Agar, Michael (1994). Language Shock: Understanding the Culture of Conversation. William Morrow Co, Inc. United States.

Avrorin, Valentin Alexandrovich (1972). Bilingualism and school. Problems of bilingualism and multilingualism. Nauka. Russia.

Baker, Colin; Jones, Sylvia Prys (1998). Encyclopedia of Bilingualism and Bilingual Education. Multilingual Matters. United Kingdom.

Balykhina, Tatiana Mikhailovna (2007). Methods of teaching Russian as a foreign language.

Publishing house of the Peoples' Friendship University of Russia. Russia

Bayatyan, Evelina (2015). Teaching linguistic disciplines to bilingual students in the context of informatization of language education. Word. Grammar. Speech. No. 16. Russia. Materials of the VI International Scientific and Practical Conference "Text: Problems and Prospects. Aspects of studying for the purpose of teaching Russian as a foreign language". Faculty of Philology, Moscow State University named after M.V. Lomonosov November 26-28, Extracted from: https://elib.grsu.by/katalog/523401pdf.pdf

Belkova, Tatiana Mikhailovna (2014). Modeling of competence-based teaching of phrasal intonation of bilingual students. Bulletin of the Chuvash State Pedagogical University named after I. Ya. Yakovlev. No. 3 (83). Russia. (Pp.103-109). Extracted from: URL: https://cyberleninka.ru/article/n/modelirovanie-kompetentnostno-orientirovannogo-

obucheniya-frazovoy-intonatsii-studentov-bilingvov

Bloomfield, Leonard (1970). Le langage. Payot. France.

Breton, Roland (1991). Geographie du plurilinguisme. Le francais dans le monde. Serie recherches et applications, vers le plurilinguisme. EDICEF. Paris. (Pp.20-32).

Bryksina, Iraida Evgenievna (2016). Linguo-methodological foundations of professionally oriented teaching of a foreign language in a non-linguistic university (bilingual / bicultural aspect). Bulletin of the Tambov University. Series: Humanities. No. 1 (153). Russia. (Pp.17-26). https://doi.org/10.20310/1810-0201-2016-21-1(153)-17-26

Derbisheva, Zamira Kasymbekovna (2015). Bilingual and polylingual education in the context of the language situation in Kyrgyzstan. Bulletin of the Peoples' Friendship University of Russia. Series: Educational issues: languages and specialties. No. 5. Russia. (Pp.7277). Extracted from: https://cyberleninka.ru/article/n/bilingvalnoe-i-polilingvalnoeobrazovanie-v-kontekste-yazykovoy-situatsii-v-kyrgyzstane

Dosanova, Altynai Zhaparovna (2015). On the formation of cognitive-communicative discursive properties of a bilingual. Questions of cognitive linguistics. No. 3 (44). Russia. (Pp.3338). Extracted from: https://cyberleninka.ru/article/n/o-formirovanii-kognitivnokommunikativnyh-diskursivnyh-svoystv-bilingva 
Dyrheeva, Galina Aleksandrovna (2017). Live speech in Buryatia: on the problem of study (sociolinguistic review). Bulletin of the Tomsk State University. Philology. No. 45. Russia. (Pp.77-88). https://doi.org/10.17223/19986645/45/5

Extracted from: URL: https://cyberleninka.ru/article/n/sotsialnye-i-lingvisticheskieaspekty-bilingvizma-i-mezhkulturnoy-kommunikatsii

Fersman, Natalia Gennadievna; Agafonova, Marina Pavlovna (2018). Bilingualism as a

Phenomenon of Intercultural Communication. KANT. No. 4 (29). Russia. (Pp.89-96).

Friedrich, Paul (1989). Language, ideology and political economy. American Anthropologist.

No. 91 (2). United States. (Pp.295-312).

Gardy, Philippe; Lafont, Robert (1981). La diglossie comme conflit: l'exemple occitan. Langages.

No. 61. France. (Pp.75-91).

Grosjean, François (1989). Neurolinguists, beware! The bilingual is not two monolinguals in one

person. Brain and language. No. 36 (1). United States. (Pp.3-15).

https://doi.org/10.1016/0093-934X(89)90048-5

Haugen, Einar Ingvald (1972). Language Science and National Language science and national development. Vol. 4. Stanford University Press. United States.

Isaev, Magomet Izmailovich (2003). Dictionary of ethnolinguistic concepts and terms. Institute of Linguistics RAS. 3rd edition. Flinta. Nauka. Rissia.

Kaspers, Olga (2017). Bilingual education in German-speaking countries: a model of transcultural learning. Bulletin of the Peoples' Friendship University of Russia. Series: Educational issues: languages and specialties. Vol. 14. No. 2. Russia. (Pp.276-286). https://doi.org/10.22363/2312-8011-2017-14-2-276-286

Kolchikova, Natalia Lavrentievna; Chebodaeva, Larisa llinichna (2018). Difficulties of perception and understanding of literary text by bilingual students. Scientific dialogue. No. 5. Russia. (Pp.290-301). https://doi.org/10.24224/2227-1295-2018-5-290-301

Kondrashkina, Elena Alekseevna (2019). Russian language in the context of language policy in the Finno-Ugric republics of the Russian Federation. Scientific dialogue. No. 10. Russia. (Pp.172-185). https://doi.org/10.24224/2227-1295-2019-10-172-185

Kruchinina, Galina Alexandrovna; Petrukovich, Lyubov Andreevna (2015). Formation of skills and abilities of professional communication in bilingual education of bachelors of international relations in the context of informatization of education. Modern problems of science and education. No. 4. Russia. (Pp.140-144). Extracted from: URL: http://scienceeducation.ru/ru/article/view?id $=20849$

Kushnyr, Lyubov Alexandrovna (2017). The cultural aspect of the formation of bilingualism among students of biology in the course of teaching a foreign language. Pedagogical sciences. No. 3 (84). Russia. (Pp.60-63). Extracted from: https://elibrary.ru/item.asp?id=29675060 
Typical mistakes in the writing speech of bilingual students.

Lambert, Wallace (1963). Psychological approaches to the study of language. The Modern Language Journal. No. 47 (3). United States. (Pp.114-121). https://doi.org/10.2307/320615

Ludi, Georges (1990). Diglossie et polyglossie. Lexikon der Pomanistischen Linguistik. Vol. 1. Kröner. Germany. (Pp.307-334).

Magomedova, Tamara Ibragimovna; Vadzhibov, Malik Jamalutdinovich (2016). Formation of the communicative competence of bilingual students: the psycholinguistic aspect. Science. Think: electronic periodical journal. No. 2. Russia. (Pp.14-17). Extracted from: URL: https://cyberleninka.ru/article/n/formirovanie-kommunikativnoy-kompetentsii-studentovbilingvov-psiholingvisticheskiy-aspekt

Maksimova, Elvira; Sarimova, Rezeda (2015). Education on a bilingual basis in the system of modern higher education. In the world of scientific discoveries. No. 11 (71). Russia. (Pp.108-114). https://doi.org/10.12731/wsd-2015-11-108-114

Matthews, Peter (1997). The Concise Oxford Dictionary of Linguistics. Oxford University Press. United Kingdom.

Mechkovskaya, Nina Borisovna (2000). Social Linguistics: A Handbook for Students in the Humanities. universities and students of lyceums. 2nd edition. Aspect Press. Russia. Mikhailov, Matvey Mikhailovich (1988). Bilingualism in the modern world. Chuvash University. Russia.

Milrud, Radislav Petrovich; Maksimova, Inna Radislavovna (2017). Educational bilingualism: yesterday, today and tomorrow. Language and culture. No. 37. Russia. (Pp.185-204). https://doi.org/10.17223/19996195/37/13

Mosin, Mikhail; Vodyasova, Lyubov; Mosina, Natalya; Chinaeva, Natalya (2017). Didactic potential of bilingualism in teaching a foreign language. Integration of education. No. 21 (4). Russia. (Pp.751-764). https://doi.org/10.15507/1991-9468.089.021.201704.751-764 Mullagayanova, Gulfia (2016). Social and linguistic aspects of bilingualism and intercultural communication. St. Petersburg educational bulletin. No. 1 (1). Russia. (Pp.15-17).

Polivara, Zinaida Vasilevna (2021). Differentiation of teaching preschoolers in the formation of lexical and grammatical categories in bilingual children in conditions of Russian-Tatar bilingualism. Education and Science. No. 2. (Pp. 105-117). https://doi.org/10.17853/1994-5639-2012-2-105-117

Risager, Karin (2005). Languaculture as a key concept in language and culture teaching. The Consequences of Mobility. Roskilde University. Denmark. Extracted from: https://rucforsk.ruc.dk/ws/files/37440173/Risager.pdf

Ryazapova, Lilia Zinnatullovna; Rozhina, V. V. (2008). Bilingualism in technical universities as a promising form of implementation of the competence-based approach in the system of two-level training of specialists. Bulletin of Kazan Technological University. No. 4. Russia. (Pp.145-147). Extracted from: https://cyberleninka.ru/article/n/bilingvizm-v- 
tehnicheskih-vuzah-kak-perspektivnaya-forma-realizatsii-kompetentnostnogo-podhoda-vsisteme-dvuhurovnevoy-podgotovki

Shcherba, Lev Vladimirovich (1974). Language system and speech activity. Nauka. Russia. Sussman, Harvey, Franklin, Philip and Simon, Terry (1989). Bilingual speech: bilateral control?

Brain and language. No. 16. United States. (Pp.125-142). https://doi.org/10.1016/0093934x(82)90052-9

Vereshchagin, Evgeny Mikhailovich (2014). Psychological and methodological characteristics of bilingualism (Bilingualism). Direct-Media. Russia.

Vishnevskaya, Galina Mikhailovna (1997). Bilingualism and its aspects. Ivanovo State University. Russia.

Vladimirova, Svetlana Gennadievna (2016). Interaction of linguistic structures in bilingualism. Yaroslavl Pedagogical Bulletin. No. 4. Russia. (Pp.156-160). Extracted from: http://vestnik.yspu.org/releases/2016_4/32.pdf

Weinreich, Uriel (1972). Monolingualism and multilingualism. New in linguistics. Issue 6. Language contacts. Russia. (Pp.25-60).

Weinreich, Uriel (1979). Language contacts. State and problems of research. Vishcha school. Publishing house at Kiev University. Kiev. Translation: Weinreich, U. Languages in contact (1970). France. 